\title{
Conference Proceesings
}

\section{Obstetrics in Islamic Medicine: An Historical Perspective}

\author{
Hossam E. Fadel, MD \\ Augusta, GA
}

\begin{abstract}
Muslims should be credited with establishing obstetrics as a separate branch of medicine. The care of the pregnant women, especially during labor and delivery, has been identified as a separate entity. Al-Räzi, in his famous book, alHâa $\bar{i}$, devotes a significant part to obstetrics. He recognizes the dangerous effects of malpresentation. He describes several abnormalities of labor including abnormalities of the delivery of the placenta. He prescribes various medicinal plants and pharmacological recipes for their treatment, including intra-uterine instillation of such medicines. Al-Zahrāwi describes in great detail the different malpresentations, how to recognize them, and the procedures to affect delivery in these situations to include internal podalic version. He recognizes that in some of these cases delivery could not be affected the "natural way" and would sacrifice the fetus to save the mother. He describes several "fetal destructive" operations including craniotomy, cleidotomy, and evisceration. He also recognized fetal abnormalities as a cause of dystocia, e.g., hydrocephalus, hydrothorax, and ascites, and he describes the procedures to affect delivery under these circumstances. Al-Zahrāwì devises, describes, and illustrates several instruments that were used to affect delivery in the different cases of dystocia.

It also seems that the early Muslim physicians were familiar with the operation of cesarean section, but it was performed only when the mother had died (or was determined to have no chance of survival) and there was a chance to rescue a live-term fetus. This is important to realize in light of a statement by an English historian (Young 1944), "Mohammedanism absolutely forbids cesarean sections and direct that any child so born must be slain forthwith, as it is the offspring of the devil." This type of statement, which defies any rational thinker or truth seeker, put a great responsibility on us to look into our history and expose the facts and discredit these myths and misinformation.
\end{abstract}

Keywords: Islamic medicine, cesarean section, history of obstetrics, history of medicine.

From the Deparlment of Obstetrics and Gynecology

Section of Perinatology

University Hospital

Augusta, GA

Reprint Requests: Dr: Hossam E. Fadel

818 St. Sebastion Way

Suile 200

Augustn, GA 30901

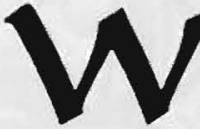

all are familiar with the significant contributions of Muslim physicians to the sciences in general and to medicine in particular. In this presentation, I am going to concentrate on contributions to obstetrics.

While it is possible that ancient Egyptians and otber early Oriental civilizations had specialized medicine, it is the Muslims who seem to have made midwifery (and the diseases of women) a special branch of the medical arts. ${ }^{1,2}$ This is to be contrasted with European medicine where gy- 
necology separated from the comprehensive field of surgery as a special discipline only in the early 19th century. The surgical textbooks, especially the numerous transcripts of Sharaf ul-din ibn Ali, (in the second half of the 15th cenlury) and works expanded at a later date gave considerable space to and detailed advice on the subject of gynecology and more particularly, obstetrics. ${ }^{3}$

'Abü Bakr Muhammad Zakariyyā al-Rāzi, the great Muslim physician, was born in 865 . He studied and worked several years in Baghdad. He later headed the hospital in al-Rayy, near Tehran, where he died in 925 . His bibliographies record 76 medical treatises. His greatest medical work is "al-Kitäb al-Häwi" (The Comprchensive book), consisting of 23 volumes. A Latin translation appeared in Sicily in 1279 as Liber Continens. ${ }^{\text {ts }}$ One of the volumes addressed the diseases of uterus, gynecology, and midwifery. In his book, al-Räzi made interesting observations:

- Fetuses born before the eighth month commonly present as breeches and they usually die.

- The fetus changes its position from breech to vertex in the eighth month because the head is the heaviest part of the body and will gravitate downwards.

$\mathrm{Al}-\mathrm{R} a \bar{z} \overline{\mathrm{I}}$ recognized that breech delivery is dangerous. He slates, "If the foot or the hand is present, it can cause death of the fetus and mother." The latter is probably a reference to transverse presentations, which lead to obsiructed labor.

He states, "Twins are delivered within few days of each other at the most." "They have been conceived together because as soon as the uterus contains the semen (probably the fertilized egg), it closes. No more "semen can enter." This probably refers to the inhibition of ovulation once fertilization occurs, the result of persistence of the corpus lureum with secretion of increasing levels of estrogen and progesterone.

Al-Rãzi also noted that "sexual intercourse brings on labor and facilitates delivery." This observation is now explained by the effect of oxytocin release and deposition of seminal prostaglandins in the vagina; both are oxytocic agents.

Al-Rāzi also noted that acute fever can cause fetal death.

He also noted that "if the breast undergoes regressive changes, the fetus will die."

Al-Ràzí noted that if labor pains are in the pelvic area labor will usually be easy, but if the pain is mostly in the lower back, labor will usually be difficult (referring to the occipito-posterior position of the fetal head).

Al-Ràzi instructed that midwives should examine the parturient before embarking on the delivery, specifically the eervix needs to be checked to see how much it is dilated, what is the presenting part, and to follow the progress of cervical dilation until it is sufficiently dilated. Then they sbould ask the parturient to push down the fetus.

Al-Rãzi described the complication of the (umbilical) cord around the neck and stated that it can be a cause of difficult labor and fetal death. He described the operation of internal podalic version and gave a brief description of the destructive operations to deliver a dead fetus.

Al-Rāzî, in his book, gives different prescriptions of medicinal herbs with their respective dosages and prescribes special kinds of food "to facilitate" labor and delivery. He describes different maternal positions to facilitate the delivery of the fetus in certain malpresentations. In difficult vertex delivery, he would have the parturient in the lithotomy position and then insert a catheter in the uterus and infuse certain fluids. If the fetus were still alive, he used fluids with lubricant effects, whereas if the fetus were dead, he used "spicy" fluids.

Al-Rāzì gave different contraceptive as well as abortifacient prescriptions.

'Abū-Qãsim Khalaf ibn al-Ábbās al-Zahrāwi (Albucasis) (936-1013 A.D.), the great Muslim surgeon, was born in 936 at al-Zahrä near Qurțobah (Cordoba), Spain. His greatest contributions are contained in the famous book " $a$ Tașrif li-man 'ajaza 'an al-Ta 'lif "or for short, "al-Tașrif" (presentation of medical knowledge for the person who cannot compile it himself). This book is known in the West as "Chinurgia." 7,8 There is a section in the book ${ }^{9}$ about "operative obstetrics," which gives a detailed account of all possible malpresentations and how to affect delivery under such circumstances. He starts with using medicines, mucilages, perfumes, changing the position of the parturient, sitting in a special seat, etc. He then describes maneuvers to facilitate delivery to include artificial rupture of membranes (AROM), internal podalic version in breech, or other malpresentations in fine detail. He recognized multifetal pregnancy. He correctly noted that twins are commonly born alive, and that triplets or quadruplets can sometimes be born alive while higher order multifetal pregnancies are usually aborted early in the pregnancy.

Al-Zähräwi devised several surgical instruments to be used in gynecological examinations and treatment; others to facilitate delivery, to extract a live fetus; and special instruments to deliver and extract dead fetuses. In his book, there are actual illustrations of these various instruments that probably formed the basis of the design for modern obstetric instruments (Figures 1-5).

I will quote his description of the operation to extract a dead fetus to show his thoroughness and the effectiveness of his technique: ${ }^{10}$

You first examine the woman to see if she is healthy or has a disease that may threaten her life. The patient is put in the lithotomy position. The vaginal opening is moistened with oils and other products. Introduce a hook and fix it to the fetus according to its presentation. If it is the head, attach the hook to the neck, mouth or beneath the chin, or if you can reach to beneath the ribs (probably in oblique or transverse lies). If the feet are presenting, fix the hook to the pelvic region. Hold the hook in the right hand and put the curved part be- 


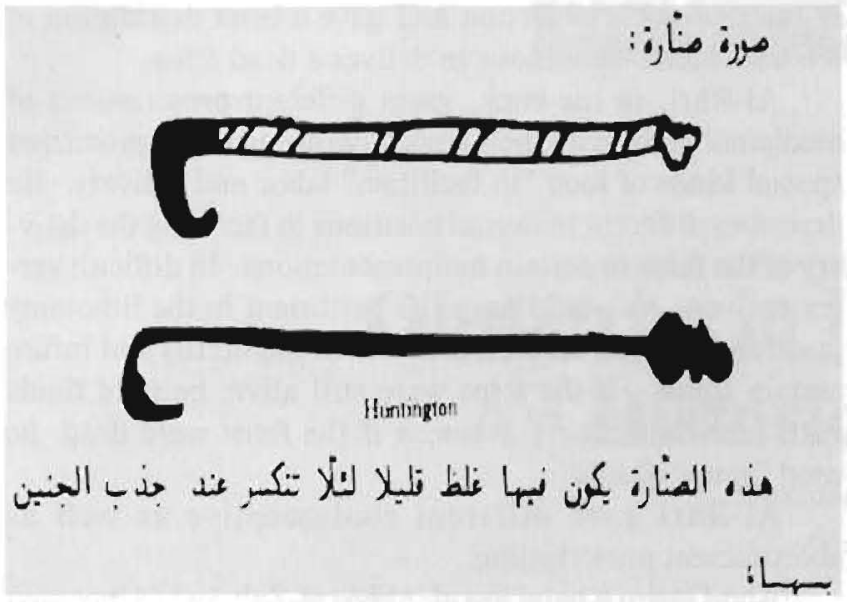

Figure 1. Different types of hooks used to deliver a dead fetus. Reproduced with permission. Wellcome Institute Library, London.

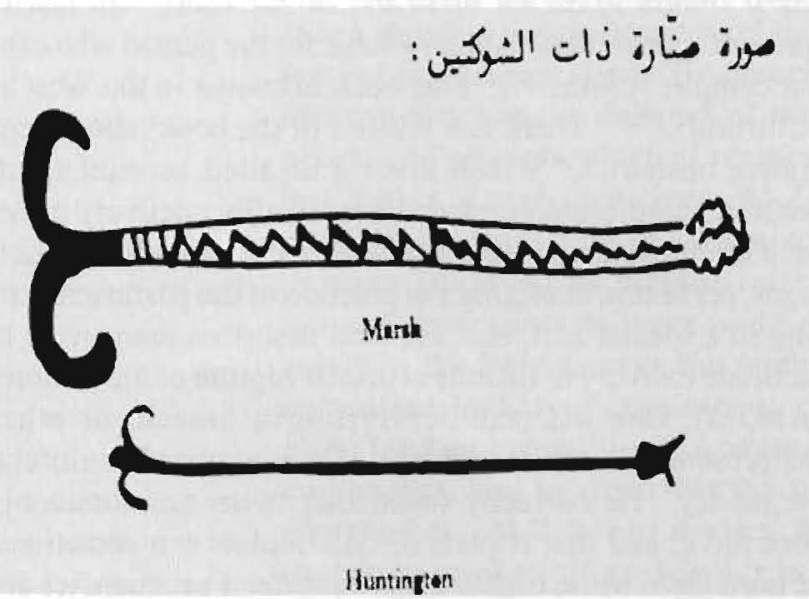

Figure 2. Inslruments (hooks) used in delivery of a dead fetus. Reproduced with permission. Wellcome Institute Library, London.

Iween the fingers of the left hand and introduce the hook gently and fix the hook as above. Then opposite it, let her (the midwife) fix another or a third hook so as to give even traction, not pulling to oneside. Then she should pull evenly not just in a straight line but with the fetus moved from side to side so that its exit may be eased. From time to ume the tension must be relaxed, and if any part of it be held up, the midwife must oil some of her lungers to introduce them to one side to manipulate the retained part. And if only a part of the fetus comes away, she should shift the hooks to other parts a little higher up and so on until the whole of the fetus comes out. (Figures 1 and 2)

He also described the operation of craniotomy (and other destructive operations) in great detail with extraordinary degree of knowledge and experience:"

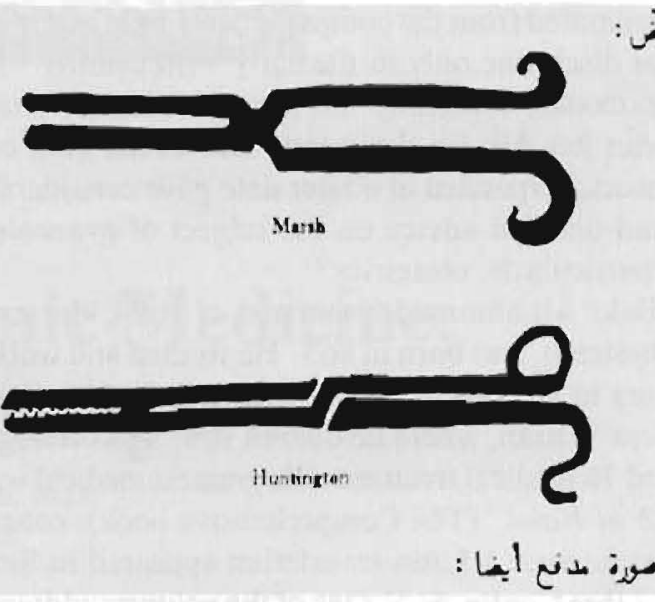

Figure 3. Instruments used to draw the fluid in cases of hydrocephaly (craniotomy scissors). Reproduced with permission. Wellcome Institute Library, London.

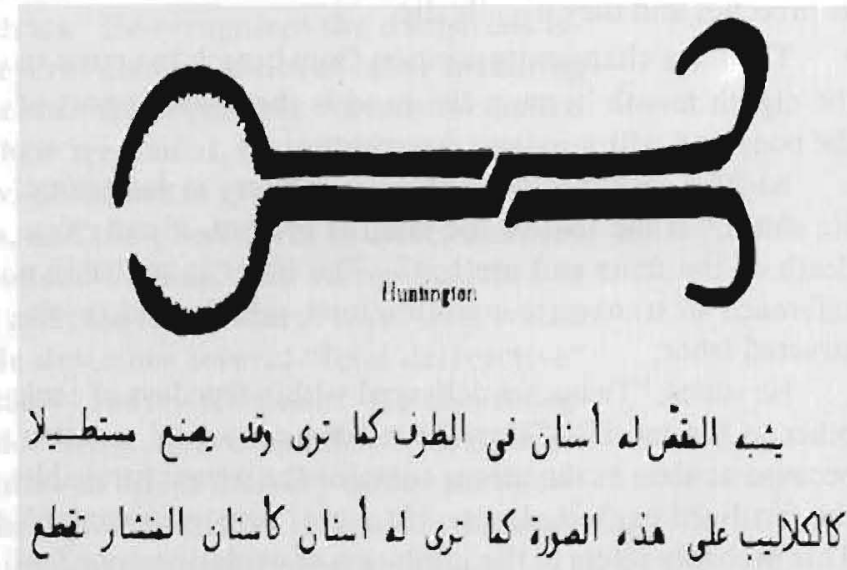

Figure 4. Instruments used to grasp the head of a dead fetus, crush it, and then deliver it (Cranioclastcephalotribe). Reproduced with permission. Wellcome Institute Library, London.

$$
\text { مرة الشداخ الذى يشدن بـ رأس الجنين: }
$$

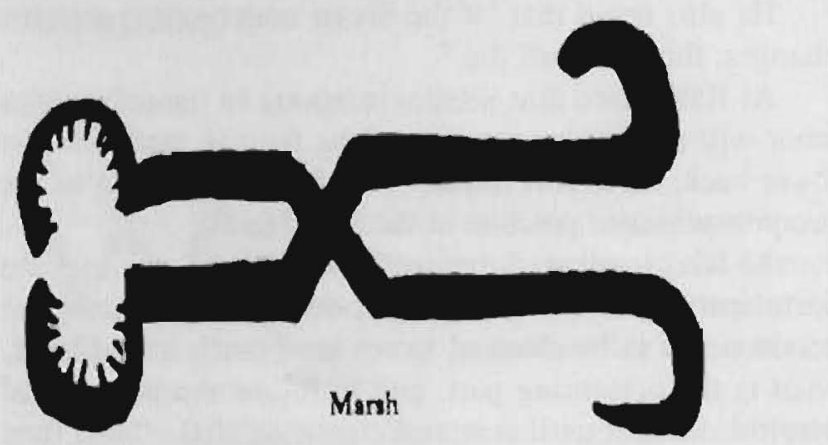

Figure 5. Instruments used to grasp the head of a dead fetus, crush it, and then deliver it. Reproduced with permission. Wellcome Institute Library, London. 
If the fetal head be large, and it is tightly squeezed in exit, or if there is a collection of fluid in the head (hydrocephalus), you should introduce between your fingers a spike shaped scalpel and split the head to let the water out (Figure 3 ) or you should smash it with the instrument called cephalotribe, then you should draw out the bones with forceps. (Figures 4 and 5) If the head comes out and the fetus is held up at the collar bones (shoulder dystocia), an incision should be made to let out the humidity in the thorax for the thorax will then shrink. But if it does not, then you cut off pieces in any manner possible (evisceration). If the lower belly be swollen or dropsical (ascites) then you should make an opening to draw out all the fluid. If the fetus presents by the feet then the extraction will be easy and it will be a simple matter to guide it to the maternal opening. If it is stuck about the thorax or abdomen, then pull on it with a cloth around your hand and cut an opening in the abdomen or thorax to allow the contents to flow out (evisceration). If the fetus presents laterally (transverse) and it is possible to reposition it (podalic version) apply the maneuvers for a living fetus, butif this is not possible then the fetus should be cut away piecemeal, then exiracted.

Al-Zahrawi stressed that the placenta should be removed completely after delivery and described methods to affect its removal: "It is necessary that not a scrap of the afterbirth be left behind in the womb." 12 Al-Zahräwi described a case of abdominal pregnancy that was mistaken for a case of IUFD. The extrauterine sac turned into an abscess, which started drainage with extrusion of the bones of the dead fetus. With proper treatment (evacution and dressing) the woman survived in good health. ${ }^{13}$

The operation of cesarean section is of particular interest boll medically and historically. The operation is unique in that it concerns two lives simultaneously, and because it brings forth a new life. It is no wonder that "abdominal delivery" has been enshrined in mythology from olden times. It is not known for certain when the first such operation was performed and whether the woman was dead or alive. The origin of the name is debated vigorously. The notion that the name was derived from the fact that Julius Caesar was delivered by this means is almost certainly erroneous, as his mother Aurelia was still alive when the emperor undertook the invasion of Britain. "Another theory is that the word is derived rom the Lalin verb "caedare," which means 10 cut, i.e. delivery by culting. ${ }^{14}$ Another theory was that Numa Pompilius, the king of Rome in 715 B.C., made a law included in the Lex Regia whereby it was forbidden to bury a pregnant woman until the child had been removed from her abdomen, even when there was but little chance of

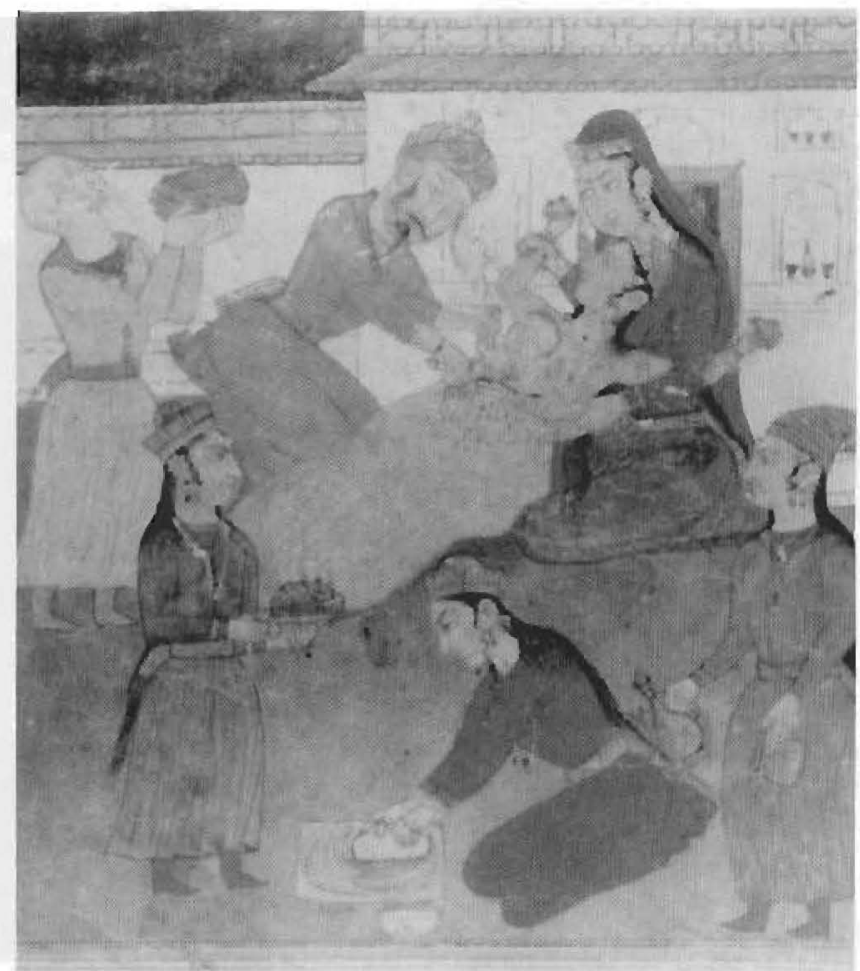

Figure 6. An illustration depicting the delivery of a fetus through the mother's abdomen (cesarean delivery). Reproduced with permission. F. Hoffman La Roche.

its survival, in order that the child and his mother be buried separately. Lex Regia became Lex Caesurea under the rule of the emperors and the operation became called cesarean operation. The first to use the term "cesarean birth" was Rousset in 1581. " The first to use the term "cesarean section" was Jacques Guillimeau in $1598 .^{16}$ However, the use of the term section became universal only in the 20th century.

While the antiquity of the operation is definitely established, it is impossible or at least very difficult to ascertain when it was first performed. According to Greek mythology and poetry, both Aesculapius, the god of Physic, and Bacchus, the god of wine, were delivered by this operation. ${ }^{14}$ Rustum, the Persian hero (the son of King Sol), was also reported to have been delivered this way. ${ }^{17}$ A painting depicting his birth is found in Firduwsi's 11 th century epic "Shah-Nameh" (The Book of Kings) ${ }^{18}$ (Figure 6). Another miniature shown here is a genuine scientific portrayal of the operation taken from the textbook of Abu-Rayhān Muhammad al-Bīrūni, "al'Āthār al-Bāqiyah 'an al-'qurūn al-Khāliyah," available at Edinburgh University library (Figure 7). ${ }^{10}$

This kind of birth, an "immaculate" one, was often taken as a sign of a high destiny. Gods and heroes tend to avoid the dark confines of the natural channels of birth. The preZoroastrian religion of the ancient Persians had a near kinship with that of the Vedic Indians. Indra, the supreme Vedic god, refuses to be born by the old well proven way. 


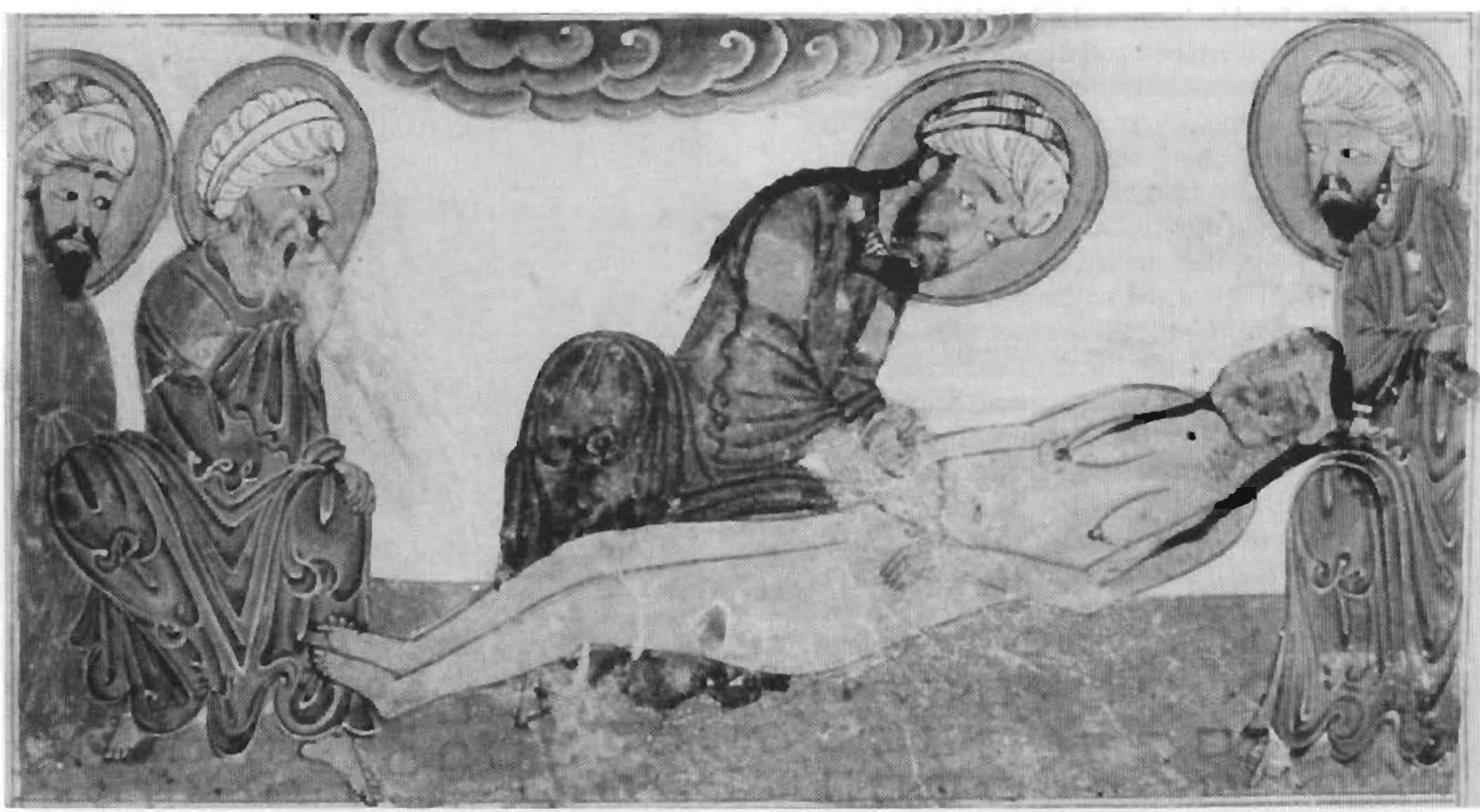

Figure 7. Another illustration of "Cesarean" delivery. Reproduced with permission. F. Hoffman La Roche.

He wants to emerge from his mother's side despite all the attendant drawbacks for her. Also, Buddha (Gautama) is reportod to have emerged pure and immaculate from the right side of his mother, Maya. ${ }^{20}$

Mythology aside, Cesarean section during earlier times was performed not on living subjects, but only on the dead if there was hope of rescuing a term child, especially if it is felt that this child may be of value to the community, an heir to the throne for example! According to Boley, the oldest authentic record of a living child born by means of this operation is Gorgias, a celebrated orator of Sicily in 508 B.C. ${ }^{14}$ It is reported that Burchard, Abbot of the St. Gallen; and Gebhard, Bishop of Constance, were born this way in 959 and 980 , respectively. It is also reported that Robert II, king of Scotland; as well as King Edward VI, son of Henry VIII and Jane Seymour, were born this way on March 2, 1316, and October 12,1537 , respectively, but probably both accounts are false. 14 There are reports of women in labor performing cesarean operations on themselves, and other reports of women gored by cows, bulls, and other horned animals with the expulsion of the fetus. ${ }^{14}$

There is no agreement among historians on when and where the first cesarean section was performed on a live woman for the purpose of delivering a live child. This is out of the scope of this paper and interested readers are referred to more recent publications. ${ }^{21,22}$

As far as religious references are concerned, the "Mischnagolh," the oldest Jewish book, published in 140
B.C., gives an account of a delivery of twins through a cut in the mother's abdomen. In the "Nidda," an appendix to the "Talmud," it is stated: "It is not necessary for a woman to observe the days of purification after the removal of a child through the parietes of the abdomen." Children delivered through the flanks of their mothers were given the name of "Jotze Dofan" by ancient Jews. ${ }^{23}$

The Roman Catholic church encouraged the use of cesarean deliveries to offer the souls of unbom children the chance of salvation through baptism. At the same time, the church banned the use of abortion, craniotomy, and fetal dismemberment as techniques to deliver the child in order to save the mother. Cesarean operations were made mandatory by the Church Councils of Cologne (1280). The Senate of the Republic of Venice laid down severe penalties for any doctor who failed to make an attempt to save the child in this way. ${ }^{21}$ During the Franciscan mission period (17691833) in the United States, the operation became the responsibility of the missionary priest who attended the dying mother. The obsession with baptism of infants was especially seen in France. Peu in his "Practique des Accouchements," published in 1694, described in great detail how baptism was to be accomplished in operative deliveries. ${ }^{21}$

In Islam, there is no direct mention of this type of delivery either in the Qur'ann or the Hadith as much as I can gather. However, Islamic principles in general will support the performance of cesarean section on a mother who just died if there is a reasonable chance to deliver a live fetus. 
This is quite evident and does not need proving. Quoting from Brandenburg, "Islam upheld the principle that is still mandatory for every obstetrician today. First, save the mother, even if the child has to be sacrificed, only once hope has been abandoned for the mother should an attempt be made to save the child (by post mortem cesarean section)." ${ }^{\prime \prime}$ In the light of this fact, it is so strange and bizarre that a physician scientist states that "Mohammedanism absolutely forbids it (i.e. cesarean section), and directs that any child so born must be slain forthwith, as it is the offspring of the devil.,"24 A statement like that without any reference or basis only belies ignorance and bigotry. Unfortunately, the same erroneous information has been restated in a more recent article, ${ }^{23}$ again without reference, but probably it was based on the statement in Young's book. ${ }^{24}$

In my preliminary and limited search in the easily available manuscripts I could find, there was no specific mention or a description of the operation. However, it is historically clear that the operation was performed during the Islamic era.

The illustration of the cesarean birth of Rustum by al-Furdūsi in his "Shah Nameh" (Book of Kings) 15601580 , in the possession of the Metropolitan Museum of Art in New York, ${ }^{18}$ indicates that he must have seen a cesarean section performed before illustrating it in his book. Al-Bīrūnī's book, "al-'Āthār al-Bāqiyah 'an alqurūn al-Khāliyah" (The chronology of ancient nations) dated 1307-8, available in Edinburgh University Library $(161 \text { folio } 6)^{19}$ reveals that in the Islamic world, the cesarean operation has not only continued to be performed under special circumstances on recently dead mothers, but has also probably been performed on living wives of Muslim kings, Sultans, and Princes to rescue both the mother and the fetus. ${ }^{25}$

This is just one example of the bigotry of Western historians who deny the contributions made by the Islamic civilization and science. Obviously, there are exceptions. There have been other historians who had endeavored to search for the facts and then report them without adulteration or bias. Examples would include some of the books I reviewed: Brandenburg,' Ullman, ${ }^{5}$ and Watt. ${ }^{26}$ Watt is quoted to have said, "for our cultural indebtedness to Islam; however, we Europeans have a blind spot. For the sake of good relations with Arabs and Muslims we must acknowledge our indebtedness to the full." 25

It behooves Muslim physicians to take the responsibility for searching our heritage and bringing the facts to life.

\section{References}

1. Brandenburg D: Islamic miniature painting in medical manuscripts. Basel, Switzerland: F. Hoffman-La Roche and Co., 1982:190.

2. Mizra MR, Siddique MI: Muslim contributions to science. Lahore, Pakistan: Kazi Publications, 1986:197.

3. Brandenburg D: 196.

4. Ibid.: 20

5. Ullman M: Islamic medicine. Edinburgh: Edinburgh University Press, 1978:43.

6. Rhazes' Liber Continens. Vol. 9. "On the diseases of the uterus, gynecology, and midwifery." Edited by the Bureau based on the unique Escurial MS (Nos 81 and 813), Madrid. Hydrabad, India, Dar-ul-Ma-árif al-uthmāniyyah, 1961:127-63 (Arabic).

7. Brandenburg D: 23.

8. Ullman $\mathrm{M}:$ 44-5.

9. Albucasis: On surgery and instruments. A derinitive edition of the Arabic text with English translation and cornmentary by M. S. Spink and GL Lewis. London: The Wellcome Institute of the History of Medicine, 1973:468-500.

10. Ibid.: 476

11. Ibid.: 478 .

12. Ibid.: 480 .

13. Ibid.: 480 .

14. Young JH: The history of cesarean section. London: H K Lewis and Co. Ltd., 1944:1-21.

15. Rousset F, Traite Nouveau de l'hysteroto mokie ou l'enfantement caesarienne" Paris 1581.

16. Guillimeau J: Childbirth or the happy deliveries of women. English translation. T. Hatfield. London: 1612. (Cited in Reference 14).

17. Young JH: 5.

18. Brandenburg D: 174,190 .

19. Ibid.: 192.

20. Ibid.: 174.

21. Hillan EM: Cesarean section: Historical background. Scot Med J 1991;36:150-4.

22. O'Dowd MJ, Phillipp EE: Cesarean section. The history of obstetrics and gynecology. New York: Partheron Publishing Group, 1994:157-165.23. Mansfield D: Edin Med J 1826;25:227 (abstract) (in Reference 14 p. 9-10).

24. Young JH: 7

25. Al-Fallouji M: Arabic Cesarean section. Islamic history and current practice. Scot Med J. 1993;38:30.

26. Watt WM: The influence of Islam on Medieval Europe. Edinburgh: Edinburgh University Press, 1972. Rer printed paperback edition 1987 (cited in Reference 25). 